\title{
Gold futures prices: an investigation into the theories of storage and forecast power and premium
}

\author{
M.J. Page \\ Graduate School of Business, University of Cape Town, Private Bag, Rondebosch, 7700 Republic of South Africa
}

\begin{abstract}
There are two principal theories of commodity futures prices. The theory of storage, which explains the difference between contemporaneous futures and spot prices (the basis) in terms of interest rates, warehousing costs, and convenience yields, and the theory of forecast power and premium, which is based on the assumption that the futures price is a biased estimate of the expected spot price. This research paper examines the applicability of the two theories to the pricing of short term gold futures contracts. The findings suggest that, in terms of the theory of storage, the basis variability is explained principally by interest rate changes for contracts of between three and six months duration, while for one-month contracts varying convenience yields appear to be the dominant factor. The low basis variability of gold futures contracts results in inconclusive findings with respect to the theory of forecast power and premium. There is, however, evidence to suggest that the basis contains some ability to predict the expected premium or bias.
\end{abstract}

Daar is twee hoof teoriee van toekomstige handelsware pryse. Die teorie van bewaring, wat die verskil tussen gelyktydige toekomstige en kontant pryse (die basis) verduidelik in terme van rentekoerse, pakhuiskoste en gerieflikheidsopbrengs, en die teorie van voorspellingskrag en premic, wat gebasseer is op die vermoede dat die toekomstige prys ' $n$ onewewigtige skatting van die verwagte kontant prys is. Dic outeur ondersoek die tocpassing van die twee teorieë van prysing van dic korttermyn toekomstige goud kontrakte. Daar word voorgestel dat in terme van die teorie van bewaring, die basiswisseling hoofsaaklik verduidelik kan word deur die rentekoersveranderings vir koptrakte van tussen drie en ses maande, terwyl vir die een-maand-lange kontrakte wisselende gerieflikheidsopbrengs skynbaar die oorheersende faktor is. Die lae basiswisseling van toekomstige goud kontrakte het die onbeslissende bevindings in verband met die teorie van voorspellingskrag en premie tot gevolg. Daar is nogtans aanduidings dat die basis moontlik die verwagte premie of onewewigtigheid kan voorspel.

\section{Introduction}

Although the origins of futures contracts can be traced back to the mid-nineteenth century it is only in the last two decades that futures trading has experienced exponential growth. To a significant extent this growth can be attributed to the fact that after 1960 trading was extended to include contracts for precious metals, currencies, and financial futures. Prior to this, futures contracts were confined to primary agricultural commodities (Sandor \& Jones, 1986: 21-23).

Two theories have been proposed to explain the pricing of futures contracts; the theory of forecast power and premium, and the theory of storage. The theory of forecast power and premium is developed from the assumption that the futures price is a biased estimate of the expected future spot price where the bias is an expected risk premium. Although research into the theory dates back to the work of Keynes (1930), the theory is still subject to considerable academic controversy. The theory of storage relates the opportunity cost of holding a commodity for future sale, as reflected in the contemporaneous difference between the spot and futures prices, to the interest foregone on the purchase price of the commodity, the cost of storing the commodity, and the convenience yield of having additional inventory (Fama \& French, 1987: 56-62). It was initially developed by Kaldor (1939) and Working (1948) and is widely accepted in the literature.

The author examines the two theories as they apply to the pricing of gold futures contracts of one-six month duration. The overall findings are that while the theory of storage is consistent with the market pricing behaviour, the results are somewhat ambiguous with respect to the theory of forecast power and premium. The varying pattern of results suggest, however, that speculators are more dominant market participants for one month contacts than for longer term contracts where pure hedging plays a greater role. This finding is supported by an analysis of the variability of both the basis and the convenience yields for different term gold futures contracts.

\section{Background}

Two principal factors contribute to the existence of futures markets. Firstly, there must be enough of the underlying standardized commodity so that economies of scale can enable frequent trading to occur (Copeland \& Weston, 1988: 309). Secondly, there must be sufficient price variability in the commodity to create a demand for risk transferance amongst hedgers and speculators. Hedgers have a future spot exposure and enter the market in order to protect themselves from adverse price changes, while speculators are prepared to bear the risk of price fluctuation with the expectation of earning additional returns.

Figure 1 illustrates the situation where market participants have homogeneous expectations about future spot prices and where there are three types of participants, namely:

a. hedgers who wish to go short in the market and wish to fix the price of future commodity sales;

b. hedgers who wish to go long in the market and wish to fix the price of future commodity purchases, and; 


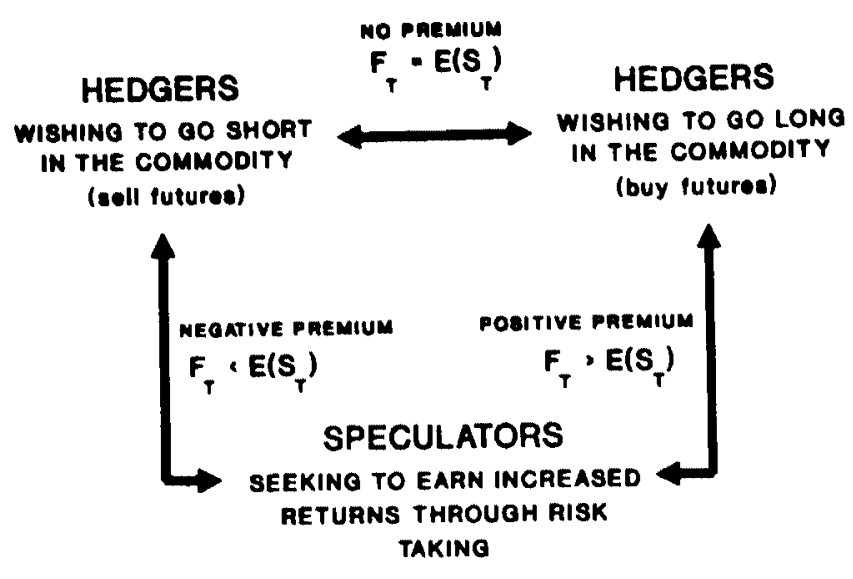

Figure 1 Participants in the futures markets

c. speculators who are prepared to bear risk in order to earn additional returns.

Given this idealized market, hedgers will transact with other hedgers who have a contrary obligation. They will trade at a futures price equal to the expected spot price since their motivation for transacting is to ensure a certain future delivery price. If hedgers require speculators to take the contrary position, however, they will have to pay a risk premium to induce them to bear the risk. Whether the futures price is above or below the expected spot price will depend on whether hedgers wish to go long or short. The futures price is below the expected spot price if producers wish to hedge their risk by selling futures contracts. In order to induce speculators to buy the contracts they have to offer them at a discount to the expected future spot price. The opposite applies if hedgers wish to go long by buying futures. In this situation they will have to offer to purchase at a premium to the expected future spot price to induce speculators to sell contracts.

In terms of the theory of forecast power and premium, the bias or expected risk premium is given by:

$E\left[P_{t, T}\right]=F_{t, T} \cdot E\left[S_{T}\right]$

where $E\left[P_{t, T}\right]=$ expected premium at time $t$ of the futures price for delivery at time $T ; E\left[S_{T}\right]=$ the expected spot price at time $T ; F_{t, T}=$ futures price at time $t$ for delivery at time $T$.

Adding the spot price at time $t$ to both sides of equation (1) and rewriting the formula, yields the final formulation of the theory. It states that the difference between the futures price and the current spot price is equal to the expected change in the spot price plus a premium of the futures price over the expected spot price (Fama \& French, 1987: 62). The formula is:

$F_{t, T}-S_{t}=E\left[P_{t, t}\right]+E\left[S_{T}-S_{t}\right]$

or equivalently

$\left[F_{t, T}-S_{t}\right] / S_{t}=E\left[P_{t, T}\right] / S_{t}+E\left[S_{T}-S_{t}\right] / S_{t}$

where $\left[F_{t, T}-S_{t}\right] / S_{t}=B_{t, T}$ is called the basis.
The controversy with the theory of forecast power and premium hinges around whether the expected premium is non-zero and whether futures prices have the power to forecast future spot prices. French tested for forecast power by regressing the change in spot price against the basis and checking for the significance of the regression equation and slope coefficient. His conclusion was that, although significant information was evident for perishable and bulk commodities, forecast power was not evident in the precious metals markets (French, 1986: s49-s50).

This work was extended by Fama and French who tested for time varying expected premiums and price forecasts in futures prices (1987: 63). Their conclusion was that a reliable split of the basis between expected premium and forecast power was not possible for precious metals (1987: 73).

According to the theory of storage the difference between a futures contract of term $T$, observed at time $t$, and the spot price at time $t$ is given by (Fama \& French, 1987: 56);

$F_{t, T}-S_{t}=S_{t} R_{t, T}+W_{t, T}-C_{t, T}$

or alternatively,

$\left[F_{t, T}-S_{t}\right] / S_{t}=R_{t, T}+\left[W_{t, T}-C_{t, T}\right] / S_{t}$

where $F_{t, r}=$ futures price at time $t$ for delivery at time $T$; $S_{t}=$ spot price at time $t ; R_{t, T}=$ the interest rate available at $t$ for a period of $T-t ; W_{t, T}=$ marginal storage or warehousing cost; $C_{r, r}=$ marginal convenience yield from having an additional unit of inventory.

Whether hedgers are long or short in the market is reflected in the convenience yield. The expected spot price is given by:

$E\left(S_{T}\right)=S_{t}+S_{t} R_{t, T}$

If hedgers wish to be long in the market then they anticipate there will be a commodity oversupply and consequently convenience yields (of having inventory) are low or negative. This results in a futures price below the expected spot price. If hedgers wish to go short in the market the reverse applies (Copeland \& Weston, 1988: 317).

If one can control for the difference between storage costs and convenience yields, the basis varies in a linear one-for-one fashion with changes in interest rates. Brennan (1958) and Telser (1958) examined the relationship between storage cost and convenience yields for agricultural commodities while Fama and French in their investigations tested for seasonals in the basis. Their findings were that metals had lower basis standard deviations than other commodities. This was attributed to the fact that metals are not subject to seasonal variation in supply and demand and have a low storage cost relative to their value (Fama \& French, 1987: 56). 


\section{Empirical procedures}

Gold futures are traded for certain standard delivery months, namely every alternate month starting with February. Additional supplementary contracts for one and two months forward are also traded. Considering only contracts of six months or less, this implies that for any particular spot month there exist either one, two, three, and five month contracts or one, two, four, and six month contracts. The data used for this study covered the period 1 August 1983-15 October 1988. Weekly closing futures prices as quoted on the New York Commodity Exchange were extracted from the Financial Times of London. Because of syncronous data problems the actual gold spot price was not used but substituted with the quote for the expiring, spot month, futures contract price (Fama \& French, 1987: 57). The data used in this study was selected to include periods of both declining and increasing gold prices. Figure 2 shows a plot of the monthly gold price over the period.

Ideally, the term structure of the interest rate data required for tests of the theory of storage should match the period of the different futures contracts. This implies that one-six month interest rate data were required. Because these data are not all quoted in the Financial Times, only the 90 day and 180 day US treasury bill rates were extracted. For each date these rates were converted from a discount to yield basis and used to estimate a yield curve using the formulae (Ehrhardt, 1984: 62):

$$
1+R_{N}=\prod_{\mathrm{n}=1}^{\mathrm{N}}\left(1+r_{n}\right)
$$

$r_{n} / r_{n-1}=c$ where $R_{N}=$ the $N$ month treasury bill rate; $r_{n}=$ the expected one month rate for month $n ; c=a$ constant.

Using the yield curves for each date the one, two, four, and five month rates were then estimated. Figure 3 shows the trend in the 90 day and 180 day treasury bill rates. From the figure it is apparent that the 180 day annualized rate is always greater than the 90 day annualized rate, and that over the entire period of study the interest rate yield curves have a positive slope.

The research procedure into the applicability of the theory of storage to the pricing of gold futures contracts involved firstly, computing the number of days to expiry and the basis data for each term futures contract. Following the procedure of Fama \& French (1987) it was assumed that futures contracts mature at the beginning of the month. This was done because, at the discretion of the seller, delivery of a futures contract can take place anywhere within the delivery month. The number of days to expiry of each futures contract was therefore calculated as the number of days from the quotation date to the start of the month during which the contract expires. This means, for example, that the 9 April 1985 futures contracts for May and June 1985 have 21 and 52 respectively to expiry. The days to expiry were needed to adjust the weekly basis figures to an annualized rate using the formula:

$B_{t, T}=\left(1+B_{t, T}\right)^{360 / d}-1$

The second stage of the procedure involved computing the means and variances of the basis data for the different period futures contracts as well as regressing the basis against the interest rate data for the one

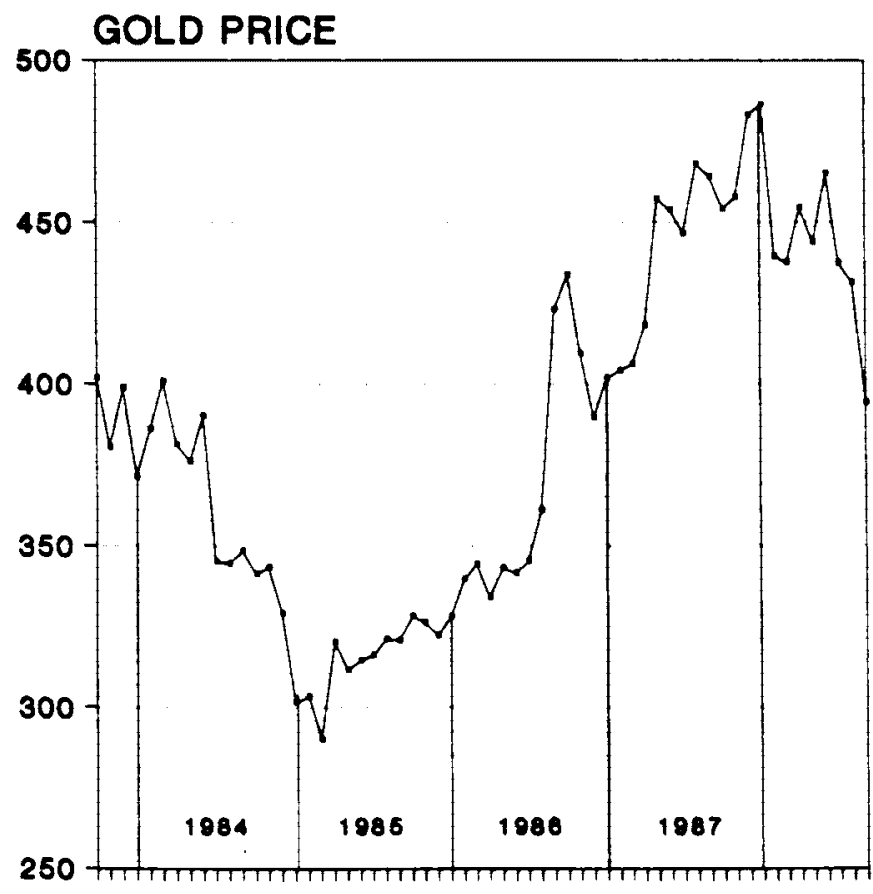

YEAR

Figure 2 Monthly spot gold price

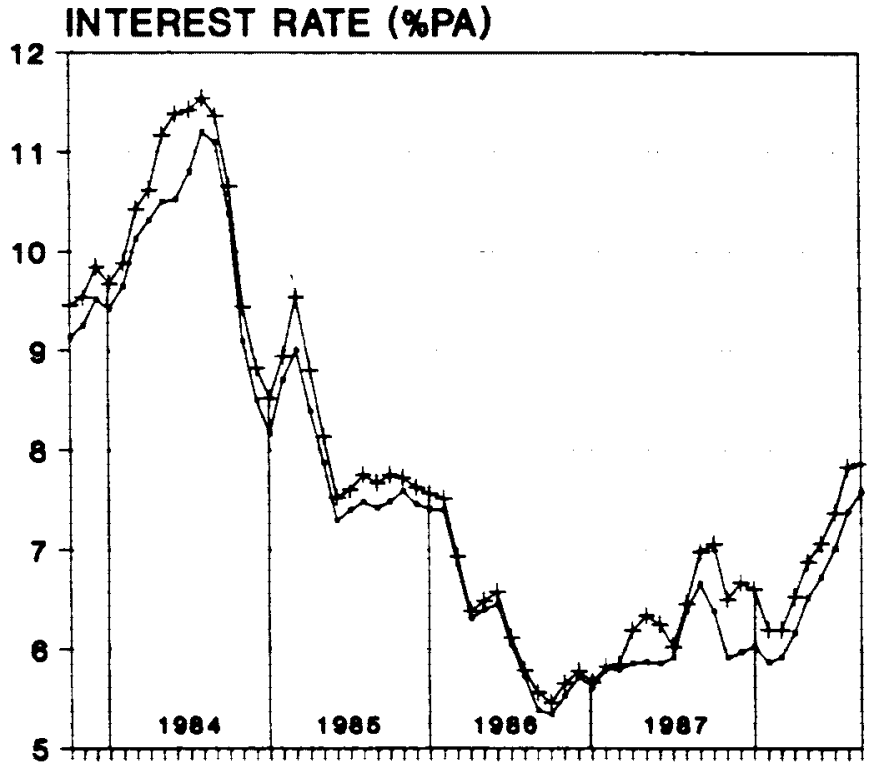

DATE

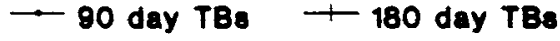

Figure 390 day and 180 day US Treasury Bill rate 
through six month contracts. Ordinary least squares regression procedures were used on the regression model:

$$
B_{t, r}=\beta_{o}+\beta_{l} R_{t, T}+\epsilon
$$

In order to establish the applicability of the theory of storage two hypothesis tests are carried out for each of the equations. Firstly, the significance of the overall regression is tested using the null hypothesis $\mathrm{H}_{0}: R^{2}=0$, and secondly, the slope coefficient $\beta_{1}$ is tested to establish if it is significantly different from one $\left(\mathrm{H}_{0}: \boldsymbol{\beta}_{1}\right.$ $1=0$ ). Finally, to assess the magnitude and consistency of the marginal warehousing costs and convenience yields, the constant $\beta_{0}$ is also tested to see if it is significantly different from zero $\left(\mathrm{H}_{0}: \beta_{0}=0\right)$.

In order to test for evidence of time varying premiums and forecast power in futures prices in terms of the theory of forecast power and premium, the basis was divided into two components.

$$
\begin{gathered}
B_{t, T}=\left[F_{t, T}-S_{t}\right] / S_{t} \\
{\left[F_{t, T}-S_{T}\right] / S_{t}-\left[S_{T}-S_{t}\right] / S_{t}}
\end{gathered}
$$

where $\left[F_{t, T}-S_{T}\right] / S_{t}=P_{t, T}$, the percentage premium of the futures price over the future spot; and $\left[S_{T}-S_{t}\right] / S_{t}=D_{t, T}$, the rate of change in the spot price from $t$ to $T$.

Two regressions were set up for each term futures contract and the regression models used for this stage of the analysis were (Fama \& French, 1987: 63);

$$
\begin{aligned}
& D_{t, T}=\beta_{2}+\beta_{3} B_{t, T}+\epsilon_{1} \\
& P_{t, T}=\beta_{4}+\beta_{5} B_{t, T}+\epsilon_{2}
\end{aligned}
$$

As discussed by Fama \& French (1987:63), regressions (12) and (13) are subject to an adding-up constraint. This implies that $\beta_{2}$ and $\beta_{4}$ sum to zero and $\beta_{3}$ and $\beta_{5}$ sum to one. It is also important to note that the regression equations are ex-post formulations of the ex-ante theory given in equation (3). The regressions are still of interest though because the coefficients $\beta_{3}$ and $\beta_{5}$ indicate the extent to which the futures price contains information about a change in the spot price, as indicated by a significant positive $\beta_{3}$, as opposed to containing information about the premium to be realized at $T$, as indicated by a significant positive $\beta_{5}$.

To test for time varying expected premiums and price forecasts in gold futures prices two hypotheses are tested for each of the regression equations. The first being that the equation itself is significant using the null hypothesis $\mathrm{H}_{0}: R^{2}=0$, and the second being that the slope coefficient is significantly positive using a one-tailed test with the null hypothesis $\mathrm{H}_{0}: \beta_{3}=0$ or $\mathrm{H}_{0}: \beta_{5}=0$.

\section{Results and Interpretation}

Table 1 summarizes the distribution of the basis data and Table 2 presents a pairwise comparison of means and variances for the different term gold futures contracts.
From the tables it is evident that the one-month basis is significantly more volatile than for the longer term contracts. The six-month basis standard deviation of $1,95 \%$ is, however, consistent with the $2,0 \%$ figure obtained by Fama \& French for data covering the period February 1975 - July 1984 (1987: 58)

In terms of the theory of storage, given the relative stability of interest rates, the one-month basis volatility can only result from variations in warehousing costs and convenience yields. As gold has standard storage arrangements with storage and handling costs being of the order of $0,04 \%$ (Fama \& French, 1987: 59) the basis volatility must be attributed to variability in convenience yields.

Table 3 outlines the results of the regressions of basis against interest rate. All the regressions are found to be significant at the $5 \%$ level. For the one- and two-month contracts the null hypothesis that the slope coefficient is not significantly different from one is rejected, as is the null hypothesis that the intercept is not significantly different from zero. The high volatility of the one-month basis is again reflected in the low coefficient of determination and comparatively high standard deviations of the slope and intercept estimates.

The influence of the increased volatility of marginal convenience yields on the one-month basis volatility is consistent with short-term changes in speculative demand for gold, and the premium or discount between the futures price and the expected spot price resulting from transactions between participants in the market. It would appear from the results that the speculative motive dominates the one-month contracts with convenience yields being the principal determinant of price. For longer term contracts the hedging motive becomes more dominant as reflected in the dominance of the cost of carry, or interest rate, component.

The non-annualized means and standard deviations for the basis, realized premiums, and changes in the spot price given in Table 4 show the low basis variability relative to its two component parts. Given that the regressions for testing the theory of forecast power and premium involve using the basis as the independent variable, this suggests that the reliability of the regression slope coefficients could be low.

The regression results of premium against basis and

Table 1 Basis means and standard deviations

\begin{tabular}{llll}
\hline $\begin{array}{l}\text { Term } \\
\text { (mths) }\end{array}$ & Obs. & $\begin{array}{c}\text { mean } \\
(\%)\end{array}$ & $\begin{array}{c}\text { SD } \\
(\%)\end{array}$ \\
\hline 1 & 214 & 7,22 & 3,30 \\
2 & 214 & 7,38 & 1,82 \\
3 & 112 & 7,60 & 1,83 \\
4 & 113 & 7,79 & 1,86 \\
5 & 112 & 7,74 & 1,92 \\
6 & 113 & 7,92 & 1,95 \\
\hline
\end{tabular}

Note: Obs. is the number of observations. SD is the annualized percentage standard deviation of the basis. 
change in spot price against basis are presented in Table 5 . For both sets of regressions, it is only for the onemonth contract that the coefficient of determination is not significantly different from zero.

The results of the hypothesis tests of the slope coefficients clearly show that only for the regressions of premium against basis are the coefficients significantly greater than zero. This finding suggests that the basis contains information about the expected premium but does not have predictive or forecast power with respect to the future spot price. This conclusion must, however, be examined in the light of the magnitude of the estimated slope coefficients. The size of the coefficients, although consistent with the results found by Fama \& French for silver, and to a certain extent gold (1987: 66), are suprising. Given the formulation of equations (11)-(13) one would expect the coefficients $\beta_{3}$ and $\beta_{5}$ to lie in the range zero-one. Clearly further examination is necessary before conclusive statements can be made about the applicability of the theory of forecast power and premium to the pricing of gold futures contracts.

\section{Conclusions}

This research investigated the applicability of the two principal theories of futures pricing to short term gold futures contracts. Although the two theories are alternative representations of the same pricing phenomena, the empirical evidence is stronger for the theory of storage than for the theory of forecast power and premium.

With respect to the theory of storage it is evident that the interest component is the major determinant of the

Table 2 Pairwise comparison of basis means and variances

\begin{tabular}{rccccc}
\hline \multicolumn{5}{c}{$\begin{array}{r}\text { Table of variance ratios } \\
\text { Denominator: Term (mths) }\end{array}$} \\
\cline { 2 - 6 } & 2 & 3 & 4 & 5 & 6 \\
\hline Numerator 1 & $3,29^{\mathrm{a}}$ & $3,27^{\mathrm{a}}$ & $3,14^{\mathrm{a}}$ & $2,95^{\mathrm{a}}$ & $2,87^{\mathrm{a}}$ \\
2 & & 0,99 & 0,95 & 0,90 & 0,87 \\
Term 3 & & & 0,96 & 0,90 & 0,88 \\
(mths) 4 & & & & 0,94 & 0,91 \\
5 & & & & & 0,97 \\
\hline
\end{tabular}

\begin{tabular}{rccccc}
\hline \multicolumn{7}{c}{ Table of difference in means } \\
\\
& 2 & 3 & 4 & 5 & 6 \\
\hline Longer term contract (mths) & & \\
\hline term 2 & & 0,22 & 0,41 & 0,36 & $0,54^{\mathrm{a}}$ \\
contract 3 & & & 0,19 & 0,17 & 0,32 \\
(mths) 4 & & & & $-0,05$ & 0,13 \\
5 & & & & & 0,18 \\
\hline
\end{tabular}

indicates significant at the $5 \%$ level. For the comparison of variances the $F$ distribution with $n_{n} ; n_{d}$ degrees of freedom is used. For the comparison of means the Students $t$ test is used allowing for unequal variances where appropriate
Table 3 Regressions of basis against interest rate data

\begin{tabular}{lcccccccc}
\hline Term & SER & $\boldsymbol{\beta}_{0}$ & $\boldsymbol{S}\left(\boldsymbol{\beta}_{0}\right)$ & $\boldsymbol{\beta}_{1}$ & $\boldsymbol{S}\left(\boldsymbol{\beta}_{1}\right)$ & $\boldsymbol{F}$ & $d f$ & $\boldsymbol{R}^{2}$ \\
1 & 3,12 & $2,35^{\mathrm{a}}$ & 0,97 & $0,66^{\mathrm{a}}$ & 0,13 & 26,71 & 212 & $0,11^{\mathrm{a}}$ \\
2 & 1,10 & $0,95^{\mathrm{a}}$ & 0,34 & $0,86^{\mathrm{a}}$ & 0,04 & 374,77 & 212 & $0,64^{\mathrm{a}}$ \\
3 & 0,82 & 0,39 & 0,35 & 0,95 & 0,05 & 437,81 & 110 & $0,78^{\mathrm{a}}$ \\
4 & 0,70 & 0,16 & 0,30 & 1,00 & 0,04 & 676,10 & 111 & $0,86^{\mathrm{a}}$ \\
5 & 0,67 & $-0,22$ & 0,29 & 1,03 & 0,04 & 816,93 & 110 & $0,88^{\mathrm{a}}$ \\
6 & 0,63 & $-0,21$ & 0,27 & 1,03 & 0,03 & 957,89 & 111 & $0,90^{\mathrm{a}}$
\end{tabular}

Note: SER is the standard error of the regression. $d f$ is the residual degrees of freedom for the $F$ statistic. aindicates significant at the $5 \%$ level for the tests; (a) $R^{2}=0$, (b) $\beta_{0}=0$, (c) $\beta_{1}-1=0$

futures price for contracts of three months or more. This suggests that investors in futures contracts of these terms are principally concerned with hedging themselves against unexpected future spot price movements. For the one-month, and possibly two-month, contracts, however, it appears that some other factor besides interest rates determines the futures price. In terms of the theory this factor must relate to a changing convenience yield. The varying convenience yield can be viewed as the result of an increasing dominance of speculators actively trading in gold futures contracts in anticipation of price fluctuations and in the hope of earning abnormal returns.

The empirical research into the theory of forecast power and premium supports the findings of Fama and French in that the low basis volatility makes it difficult to meaningfully sub-divide the basis into its two component parts of forecast power and premium. There is, however, some evidence to suggest that the basis contains information about the expected premium rather than providing a reliable forecast of future spot prices. For the two- to six-month contracts the slope coefficients were found to be significantly greater than zero for the regressions of realized premium against basis.

Considerably more research is required before the current debate into the general issue of whether the expected premium can be non-zero is finally resolved.

Table 4 Basis, premium, and change in spot price means and standard deviations

\begin{tabular}{lccccccc}
\hline & & \multicolumn{2}{c}{ Basis } & \multicolumn{3}{c}{ Premium } & \multicolumn{2}{c}{ Change in spot } \\
\cline { 3 - 8 } Term & Obs. & Mean & SD & Mean & SD & Mean & SD \\
$($ mths $)$ & & $(\%)$ & $(\%)$ & $(\%)$ & $(\%)$ & $(\%)$ & $(\%)$ \\
\hline 1 & 204 & 0,35 & 0,20 & 0,46 & 4,16 & $-0,11$ & 4,15 \\
2 & 200 & 0,96 & 0,28 & 0,85 & 6,42 & 0,11 & 6,34 \\
3 & 108 & 1,63 & 0,42 & 0,99 & 7,50 & 0,65 & 7,35 \\
4 & 105 & 2,32 & 0,56 & 2,19 & 8,06 & 0,13 & 7,73 \\
5 & 103 & 2,97 & 0,76 & 1,97 & 9,49 & 1,00 & 9,07 \\
6 & 102 & 3.70 & 0,94 & 2,49 & 10,42 & 1,21 & 9,77 \\
\hline
\end{tabular}

Note : Percentage figures (returns) have not been annualized 
Table 5 Regressions of change in the spot price against basis and premium against basis

\begin{tabular}{|c|c|c|c|c|c|c|c|c|c|c|}
\hline Term & $S E R$ & $\boldsymbol{\beta}_{3}$ & $\beta_{5}$ & $\mathbf{s}(\beta)$ & $d f$ & $F_{s}$ & $R_{\mathrm{s}}^{2}$ & $F_{p}$ & $R_{\mathrm{p}}^{2}$ & \\
\hline 1 & 4,16 & $-0,92$ & 1,92 & 1,45 & 202 & 0,40 & 0,00 & 1,76 & 0,01 & \\
\hline 2 & 6,12 & $-6,21$ & $7,21^{a}$ & 1,56 & 198 & 15,98 & $0,08^{a}$ & 21,54 & $0,10^{\mathrm{a}}$ & \\
\hline 3 & 6,99 & $-5,69$ & $6,69^{\mathrm{a}}$ & 1,62 & 106 & 12,37 & $0,10^{4}$ & 17,09 & $0,14^{a}$ & \\
\hline 4 & 6,48 & $-7,66$ & $8,66^{a}$ & 1,14 & 103 & 45,28 & $0,31^{\star A}$ & 57,88 & $0,36^{\mathrm{a}}$ & \\
\hline 5 & 7,79 & $-6,24$ & $7,24^{a}$ & 1,02 & 101 & 37,42 & $0,27^{a}$ & 50,38 & $0,33^{\mathrm{a}}$ & \\
\hline 6 & 7,30 & $-6,99$ & $7,99^{a}$ & 0,78 & 100 & 81,04 & $0,45^{\mathrm{a}}$ & 105,90 & $0,51^{\mathrm{a}}$ & \\
\hline
\end{tabular}

$S E R$ is the standard error of the regression. $d f$ is the residual degrees of freedom for the $F$ statistic.

$\beta_{3}, F_{s}, R_{s}^{2}$ refer to the regression of change in spot price against basis.

$\beta_{5}, F_{p}, R_{p}^{2}$ refer to the regression of premium against basis.

a indicates significant at the $5 \%$ level for the tests; (a) $R^{2}=0$, (b) $\beta_{3}=0$ vs $\beta_{3}>0$, (c) $\beta_{5}=0$ vs $\beta_{5}>0$

\section{Acknowledgement}

The author wishes to thank O.C. Ryan for his assistance during the initial stages of this project.

\section{References}

Brennan, M.J. 1958. The supply of storage. Am. Econ. Rev., no.48, 50-72.

Copeland, T.E. \& Weston, J.F. 1988. Financial Theory and Corporate Policy, 3rd. ed. Addison-Wesley Publishing Company.

Ehrhardt, M.C. 1984. Arbitrage Pricing Theory and the term structure of interest rates. Unpublished Ph.D. Thesis, Georgia Institute of Technology.

Fama, E.F. \& French, K.R. 1987. Commodity Futures Príces:
Some Evidence on Forecast Power, Premiums, and the Theory of Storage. J. Bus., vol.60(1), 55-73.

French, K.R. 1986. Detecting Spot Price Forecasts in Future Prices. J. Bus., vol.59(2), S39-S54.

Kaldor, N. 1939. Speculation and Economic stability. Rev. Econ. Studies, no.7, 1-27.

Sandor, R.L. \& Jones, D. 1986. Futures and Commodities Markets. Fin. Hdbk., 5th ed. Edited by Edward I. Altman. New York: John Wiley and Sons.

Telser, L.G. 1958. Futures trading and the storage of cotton and wheat. J. Pol. Econ., no.66, 233-255.

Working, H. 1948. Theory of the inverse carrying charge in futures markets. J. Farm Econ., no.30, 1-28. 